\title{
A preliminary assessment on the plankton diversity of Serlui 'B' dam in Mizoram, northeast India
}

\author{
Esther Lalhmingliani, ${ }^{*}$ Freddy Lalrinpuia \\ Department of Zoology, Mizoram University, Aizawl 796004, India
}

\begin{abstract}
Planktonic sampling was carried out at Serlui 'B' dam, Mizoram, northeast India from July 2016 to April 2017. The present study reported the occurrence of 6 groups of phytoplankton belonging to 27 genera and 16 orders and 4 groups of zooplanktons belonging to 12 genera 7 orders. The phytoplankton group consisted of Cyanophyceae, Bacillariophyceae, Ulvophyceae, Zygnematophyceae, Chlorophyceae and Xanthophyceae. Cyanophyceae were the predominant component of phytoplankton in Serlui 'B' dam during all seasons in terms of numerical abundance and account for $64 \%$ of the total phytoplankton. The zooplankton groups consisted of Maxillopoda, Tubulinea, Eurotatoria and Branchiopoda. Of these, the class Maxillopoda was the predominant component of zooplankton in Serlui ' $B$ ' dam during all season in terms of numerical abundance and account for $73 \%$ of the total zooplankton encountered from the study site. This study provides preliminary report of planktons of Serlui 'B' dam.
\end{abstract}

Key words: Mizoram; phytoplankton; Serlui 'B' dam; zooplankton.
Received 18 November 2017 Accepted 30 November 2017

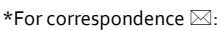
esther1gralte@gmail.com

\section{Introduction}

The requirement of water in all life forms, from microorganism to man is a serious problem today because majority of the water resources have reached a point of crises due to unplanned urbanization and industrialization which significantly contributes to the pollution and toxicity of aquatic ecosystems. ${ }^{1}$ The physico -chemical characteristics of the aquatic environment directly influence the life inhabiting it. Pollutants not only bring about a change in the physico-chemical characteristics of water, but often create an adverse environment to organisms resulting in the elimination of some valuable species and cause a change in the dominant biota. ${ }^{2}$ Species diversity is adversely affected by a marked change in the algal community. ${ }^{3}$ Due to their rapid response to toxins and other chemicals, phytoplankton is considered as one of the most reliable detectors of environmental change. However, their scant distribution along with their transient nature cannot be totally relied upon for assessing the quality of water. The present study focused on the abundance and distribution pattern of plankton in Serlui 'B' dam, an earth fill gravity dam on the Serlui river, $12 \mathrm{~km}$ from Bilkhawthlir village, Kolasib district, Mizoram, northeast India.

\section{Materials and Methods}

The present study was undertaken in Serlui 'B' dam located in Mizoram, northeast India be- 
tween $24^{\circ} 20^{\prime} 18.18^{\prime \prime} \mathrm{N}$ latitude and $92^{\circ} 46^{\prime} 06.48^{\prime \prime} \mathrm{E}$ longitude. Serlui River flows through Kolasib district and is impounded by the Serlui 'B' Dam, an earth fill gravity dam located $12 \mathrm{~km}$ from Bilkhawthlir village, Kolasib district, Mizoram. It is the largest hydro-power plant in Mizoram with a height of $51 \mathrm{~m}$ and length of $293 \mathrm{~m}$. The catchment area is about $53 \mathrm{~km}$ wide thick forest.

Water samples were collected from the study site with a wide mouth plastic bottle on a monthly basis from July 2016 to April 2017. Plankton were collected by submerging plankton net to a maximum depth while slowly turning the inlet in the front direction covering as much area as possible. The plankton thus collected at the tube from the end of the net were then transferred to the sample bottle and then fixed with formalin. The samples were then brought to the laboratory, Department of Zoology, Mizoram University for qualitative and quantitative analysis of plankton. The water samples containing the plankton were dropped on the slides and were then observed under microscope for the assessment of plankton diversity. Surface unit was selected instead of volume unit since it showed the actual numbers of individuals present per sq. cm. All individuals present in the sample were counted and photograph was taken. Identification was done up to the genus level with the help of published literature.5-9

\section{Results and Discussion}

In total, 27 genera of phytoplankton belonging to 15 orders and 6 groups were identified and quantified from Serlui' 'B' dam (Table 1). The group consisted of Cyanophyceae, Bacillariophyceae, Ulvophyceae, Zygnematophyceae, Chlorophyceae and Xanthophyceae (Fig. 1). Cyanophyceae were the predominant component of phytoplankton during all seasons in terms of numerical abundance. They account for $67 \%$ of the total phytoplankton group and were represented by 6 genera viz. Rivularia, Nostoc, Microcystis, Oscillatoria, Spirulina and Anabaena. Rivularia belonging to order Nostocales was the most dominant Cyanaophyceae and comprises $88 \%$ of the group and $59 \%$ of the total phytoplankton.
Baccilariophyceae formed the second most dominant group and comprises about $13 \%$ of the total phytoplankton count. They were mostly represented by Diatoma belonging to order Pennales. Although Zygnematophyceae were represented by maximum number of genera, collectively they form only about $9 \%$ of the total phytoplankton encountered in the study site. Lowest recorded phytoplankton abundance was Xanthophyceae represented by ophiocytium which comprises less than $1 \%$ of the total phytoplankton community. The least dominant genera were that of Gonatozygon, Sirogonium, Meridion and Cylindrocystis, each represented by 1 individual. Overall, summer season harbors maximum number of phytoplankton where $58 \%$ of the total phytoplankton was encountered (Fig. 2). Abundance was at its lowest during the spring season where only $11 \%$ of the total phytoplankton was reported, but practically the same groups and genus were dominant, although they were present in smaller numbers. Of the total 27 genera of phytoplankton encountered during the study period, Ophiocytium is the only phytoplankton found only during the spring season. Spirulina, Sirogonium, Gonatozygon, Cylindrocystis and Ankistrodesmus were encountered only during summer season while Meridion and Pandorina were encountered during the winter season only (Fig. 3 and 4). With regards to species composition Zygnematophyceae consisting of 10 genera were the most diversified although they form the third most dominant group among the phytoplankton.

Phytoplankton is useful in biomonitoring the ecological disturbance caused by a number of physico-chemical factors, sewage pollutants and other anthropogenic factors. ${ }^{10-12}$ The dominance of Chlorophyceae and Bacillariophyceae was observed in oligotrophic reservoirs whereas in eutrophic reservoirs, dominance of Cyanophyceae was observed ${ }^{13}$ Many algal species such as Euglena, Oscillatoria, Scenedesmus, Navicula, Nitzschia and Microcystis belonging to Chlorophyceae, Cyanophyceae, Euglenophyceae and Bacillariophyceae usually inhabit organically polluted waters and are used as indicators of water quality. ${ }^{14,15}$ It has also been reported that Microcystis 
Table 1 | List of phytoplankton of Serlui 'B' dam.

\begin{tabular}{|c|c|c|c|c|c|c|c|c|c|c|c|c|}
\hline \multirow[t]{2}{*}{ No } & \multirow[t]{2}{*}{ Phytoplankton } & \multicolumn{4}{|c|}{ Summer } & \multicolumn{3}{|c|}{ Winter } & \multicolumn{3}{|c|}{ Spring } & \multirow[t]{2}{*}{ Total } \\
\hline & & July & Aug & Sept & Oct & Nov & Dec & Jan & Feb & Mar & Apr & \\
\hline \multirow[t]{11}{*}{1} & Cyanophyceae & & & & & & & & & & & \\
\hline & a) Nostocales & & & & & & & & & & & \\
\hline & Rivularia & 143 & 237 & 98 & 100 & 130 & 5 & 20 & 17 & 22 & 29 & 801 \\
\hline & Nostoc & 33 & 3 & 1 & 2 & 0 & 35 & 0 & 0 & 0 & 0 & 74 \\
\hline & Anabaena & 6 & 0 & 2 & 3 & 2 & 6 & 1 & 0 & 0 & 0 & 20 \\
\hline & b) Chroococcales & & & & & & & & & & & \\
\hline & Microcystis & 3 & 0 & 0 & 0 & 0 & 1 & 0 & 0 & 0 & 0 & 4 \\
\hline & c) Oscillatoriales & & & & & & & & & & & \\
\hline & Oscillatoria & 5 & 0 & 0 & 0 & 0 & 1 & 0 & 2 & 0 & 0 & 8 \\
\hline & d) Spirulinales & & & & & & & & & & & \\
\hline & Spirulina & 3 & 0 & 0 & 0 & 0 & 0 & 0 & 0 & 0 & 0 & 3 \\
\hline \multirow[t]{9}{*}{2} & Bacillariophyceae & & & & & & & & & & & \\
\hline & a) Naviculales & & & & & & & & & & & \\
\hline & Pinnularia & 6 & 0 & 1 & 0 & 0 & 2 & 0 & 0 & 0 & 0 & 9 \\
\hline & Navicula & 4 & 6 & 1 & 0 & 0 & 0 & 17 & 6 & 6 & 5 & 45 \\
\hline & Stauroneis & 1 & 1 & 1 & 0 & 0 & 0 & 5 & 0 & 0 & 2 & 10 \\
\hline & b) Pennales & & & & & & & & & & & \\
\hline & Diatoma & 18 & 7 & 5 & 4 & 3 & 9 & 26 & 7 & 12 & 21 & 112 \\
\hline & c) Tabellariales & & & & & & & & & & & \\
\hline & Meridion & 0 & 0 & 0 & 0 & 0 & 1 & 0 & 0 & 0 & 0 & 1 \\
\hline
\end{tabular}

3 Ulvophyceae

a) Ulotrichales

Ulothrix

4

$8 \quad 0$

2

32

5

3

36

36

4 Zygnematophyceae

a) Desmidiales

\begin{tabular}{|c|c|c|c|c|c|c|c|c|c|c|c|}
\hline Cosmarium & 6 & 1 & 1 & 0 & 2 & 1 & 0 & 0 & 0 & 0 & 11 \\
\hline Docidium & 6 & 0 & 0 & 0 & 0 & 0 & 0 & 2 & 2 & 1 & 11 \\
\hline Gonatozygon & 1 & 0 & 0 & 0 & 0 & 0 & 0 & 0 & 0 & 0 & 1 \\
\hline Desmidium & 0 & 0 & 13 & 7 & 3 & 0 & 3 & 0 & 0 & 0 & 26 \\
\hline $\begin{array}{l}\text { Closterium } \\
\text { ygnematales }\end{array}$ & 0 & 0 & 0 & 0 & 0 & 0 & 0 & 2 & 0 & 1 & 3 \\
\hline Spirogyra & 2 & 5 & 0 & 0 & 0 & 2 & 4 & 4 & 2 & 8 & 27 \\
\hline Mougeotia & 5 & 2 & 1 & 7 & 8 & 5 & 3 & 2 & 3 & 7 & 43 \\
\hline Zygnema & 0 & 2 & 0 & 1 & 2 & 0 & 0 & 0 & 0 & 0 & 5 \\
\hline Sirogonium & 0 & 0 & 0 & 1 & 0 & 0 & 0 & 0 & 0 & 0 & 1 \\
\hline Cylindrocystis & 0 & 0 & 0 & 1 & 0 & 0 & 0 & 0 & 0 & 0 & 1 \\
\hline
\end{tabular}

5 Chlorophyceae

a) Oedogoniales

Oedogonium

b) Sphaeropleales

$\begin{array}{lllllllllll}\text { Ankistrodesmus } & 2 & 0 & 0 & 0 & 0 & 0 & 0 & 0 & 0 & 0\end{array}$

c) Microsporales

Microspora

d) Volvocales

Pandorina

$\begin{array}{llllll}5 & 0 & 0 & 3 & 18 & 3\end{array}$

$0 \quad 0$

0

29

6 Xanthophyceae

$\begin{array}{lllllllllll}0 & 0 & 0 & 0 & 4 & 3 & 8 & 6 & 0 & 0 & 21\end{array}$

a) Mischococcales

Ophiocytium Total

$\begin{array}{cccccc}0 & 0 & 0 & 0 & 0 & 0 \\ 263 & 274 & 127 & 134 & 188 & 78\end{array}$

103

56

61

0

6 
Table 2 | List of zooplankton of Serlui 'B' dam.

\begin{tabular}{|c|c|c|c|c|c|c|c|c|c|c|c|c|}
\hline \multirow[t]{2}{*}{ No } & \multirow[t]{2}{*}{ Zooplankton } & \multicolumn{4}{|c|}{ Summer } & \multicolumn{4}{|c|}{ Winter } & \multicolumn{2}{|c|}{ Spring } & \multirow[t]{2}{*}{ Total } \\
\hline & & July & Aug & Sept & Oct & Nov & Dec & Jan & Feb & Mar & Apr & \\
\hline \multirow[t]{6}{*}{1} & $\begin{array}{l}\text { Maxillopoda } \\
\text { (Copepoda) } \\
\text { a) Cyclopoida }\end{array}$ & & & & & & & & & & & \\
\hline & Nauplius & 0 & 0 & 0 & 0 & 3 & 0 & 0 & 2 & 5 & 5 & 15 \\
\hline & Cyclops & 8 & 2 & 6 & 5 & 11 & 4 & 0 & 5 & 4 & 6 & 51 \\
\hline & b) Calanoida & & & & & & & & & & & \\
\hline & Calanoid & 5 & 0 & 1 & 2 & 36 & 1 & 2 & 13 & 8 & 3 & 71 \\
\hline & Diaptomus & 0 & 0 & 0 & 0 & 5 & 0 & 0 & 0 & 1 & 0 & 6 \\
\hline
\end{tabular}

\section{Tubulinea}

a) Arcellinida

$$
\text { Arcella }
$$

3 Eurotatoria (Rotifera)
a) Ploima

Keratella

1

4 Branchiopoda

a) Cladocera

$\begin{array}{llllllllllll}\text { Alona } & 3 & 0 & 2 & 7 & 2 & 0 & 0 & 12 & 2 & 0 & 28 \\ \text { Bosmina } & 0 & 0 & 0 & 0 & 0 & 0 & 0 & 2 & 4 & 0 & 6 \\ \text { Acroperus } & 0 & 0 & 0 & 1 & 0 & 0 & 0 & 0 & 0 & 0 & 1 \\ \text { Anostraca } & & & & & & & & \end{array}$

b) Anostraca

$\begin{array}{llllllllllll}\text { Eubranchipus } & 0 & 0 & 0 & 1 & 0 & 0 & 0 & 8 & 0 & 0 & 9\end{array}$

c) Diplostraca

Chydorus

Sida Total

$\begin{array}{cccc}0 & 0 & 0 & 0 \\ 0 & 1 & 0 & 0 \\ 18 & 6 & 9 & 16\end{array}$

$\begin{array}{ccccccc}0 & 1 & 0 & 0 & 0 & 0 & 1 \\ 0 & 0 & 0 & 0 & 0 & 0 & 1 \\ 59 & 6 & 2 & \mathbf{4 2} & \mathbf{2 4} & \mathbf{1 6} & \mathbf{1 9 8}\end{array}$

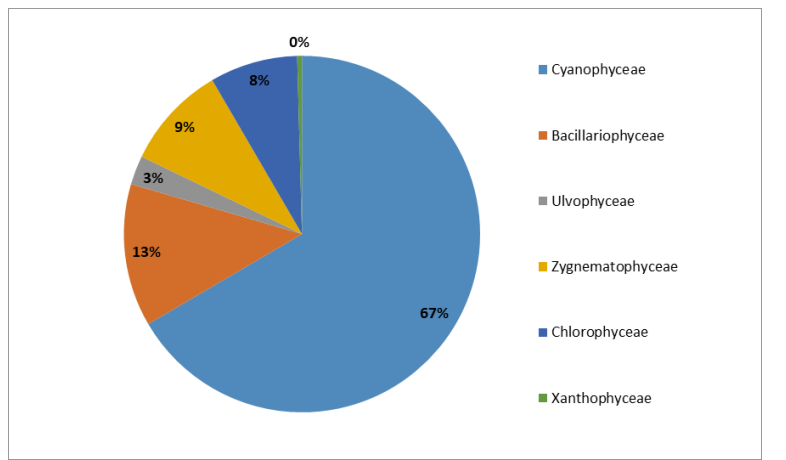

Fig. 2 | Seasonal distribution of phytoplankton in Serlui 'B' dam.

aeruginosa was associated with the highest degree of civic pollution and was used as the best single indicator of pollution. ${ }^{16}$ The present investigation recorded the occurrence of Microcystis along with Oscillatoria and Navicula from the study site thereby indicating that the dam is organically polluted. Serlui 'B'dam is subjected to

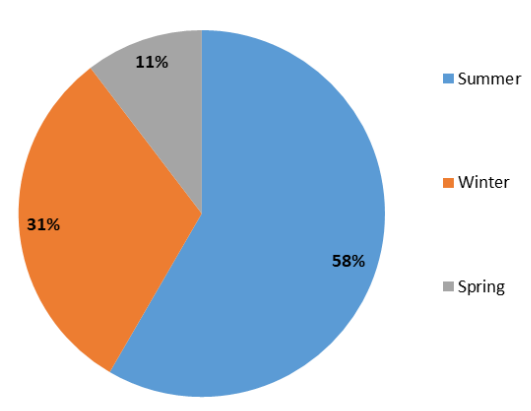

Fig. 3 | Phytoplanktons of Serlui 'B' dam.

pollution due to addition of fertilizers from agricultural lands and domestic sewage. Progressive enrichment of water with nutrients leads to mass production of algae, which in turn leads to the increased productivity and other undesirable biotic changes. The nutrient status, age, morphometry and other locational factors of differ- 


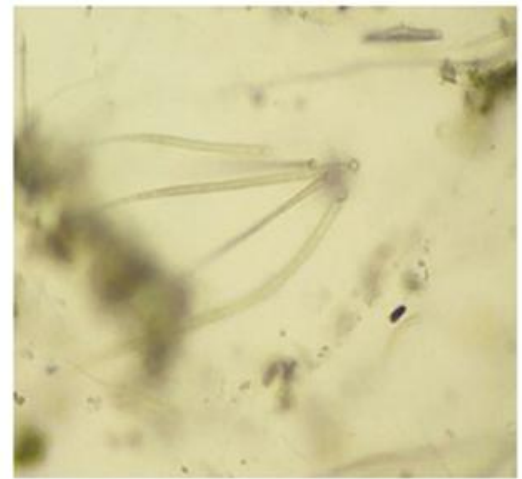

a) Rivularia

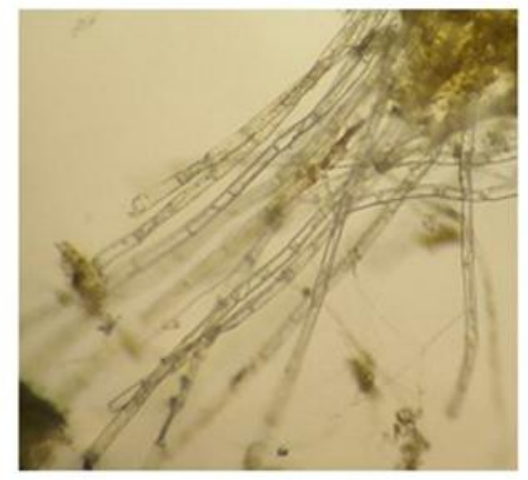

d) Oedogonium

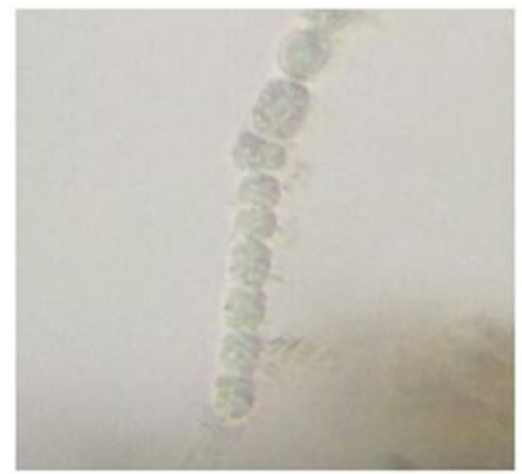

g) Anabaena

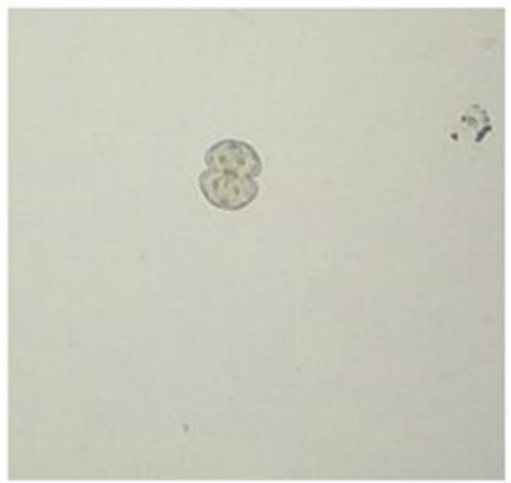

b) Cosmarium

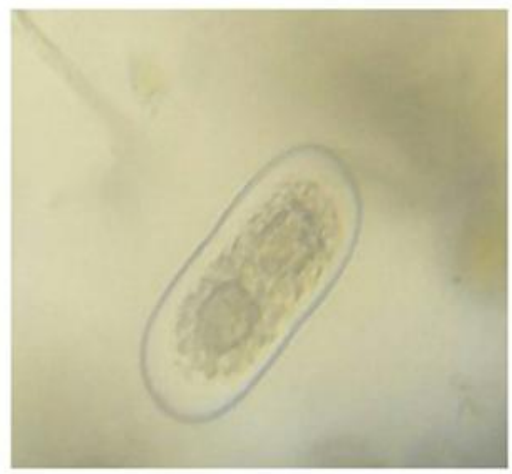

e) Cylindrocystis

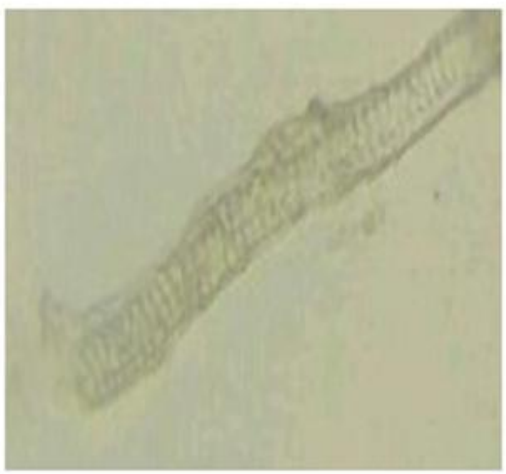

h) Spirogyra

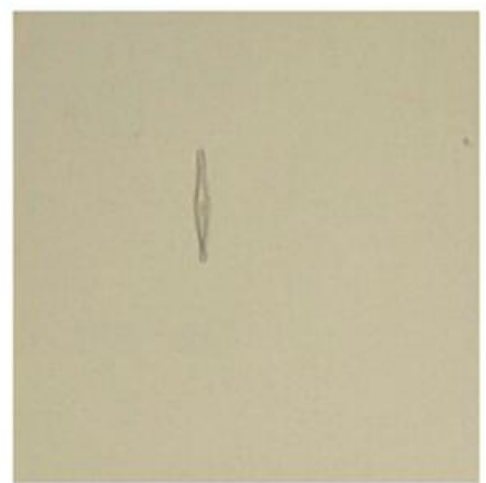

c) Diatoma

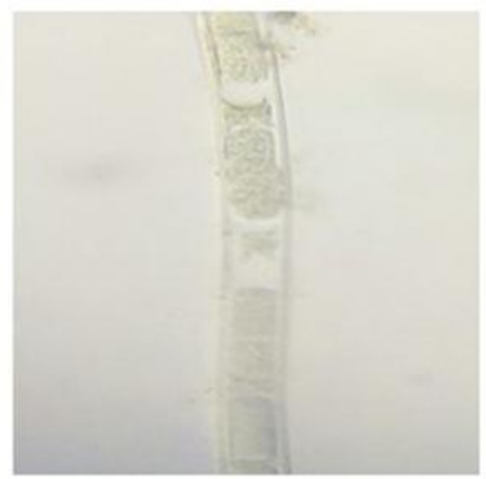

f) Mougeotia

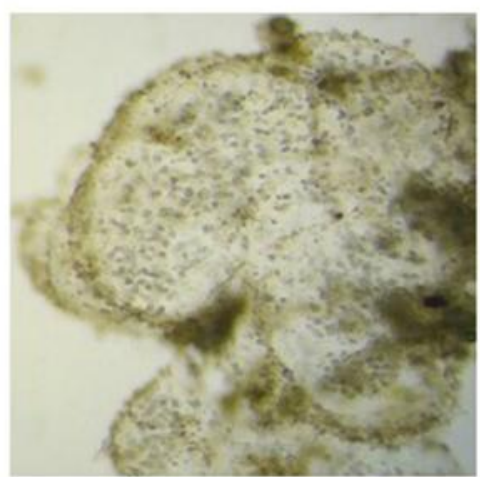

i) Microcystis

Fig. 3 | Phytoplanktons of Serlui 'B' dam. 


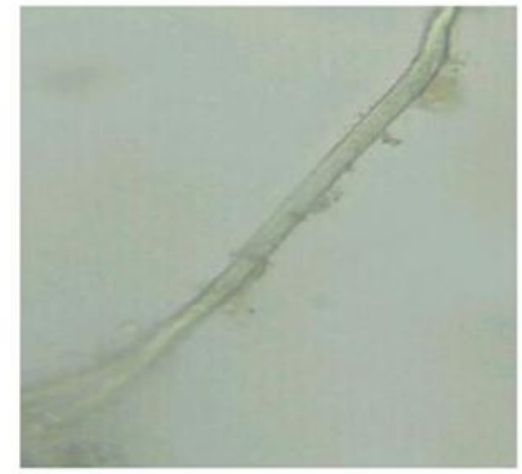

j) Docidium

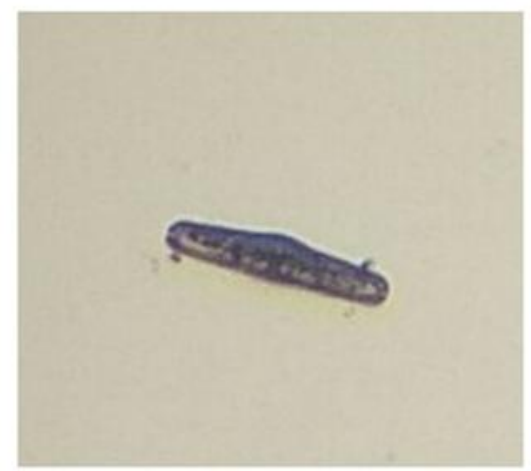

m) Pinnularia

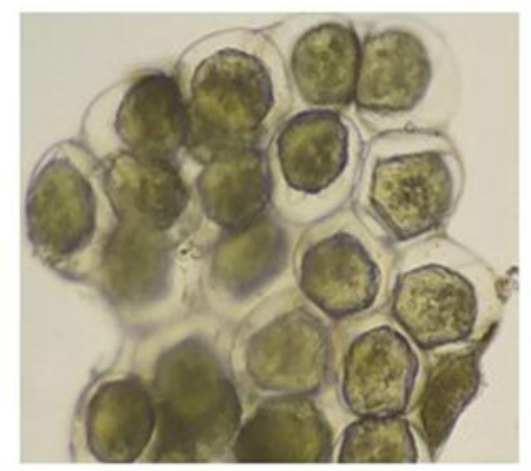

p) Pandorina

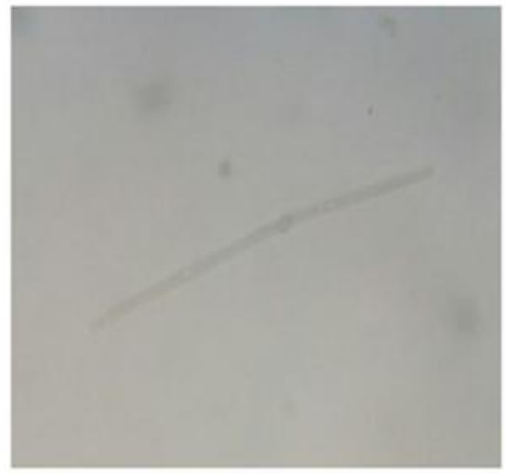

k) Nostoc

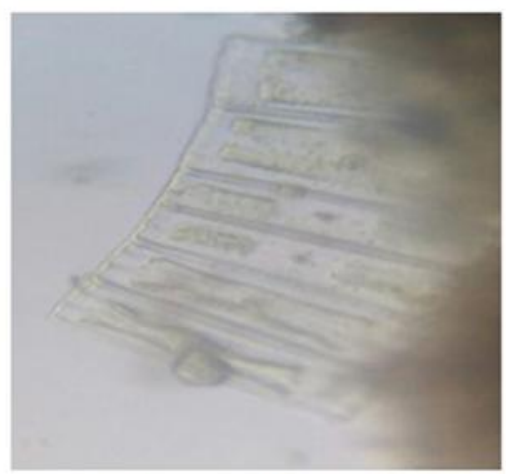

n) Meridion

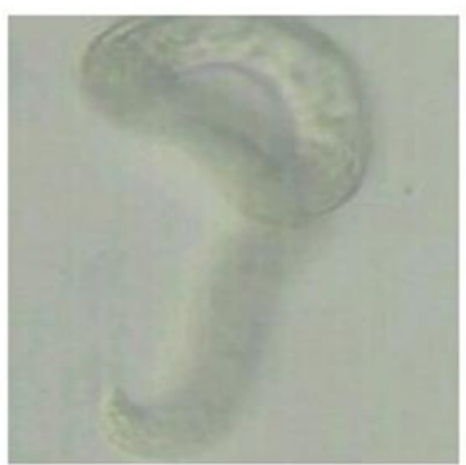

q) Ophiocytium

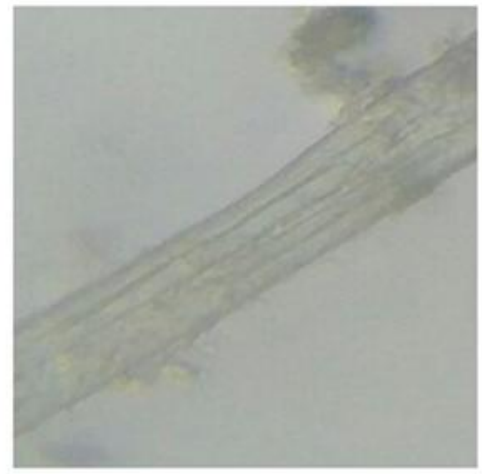

I) Oscillatoria

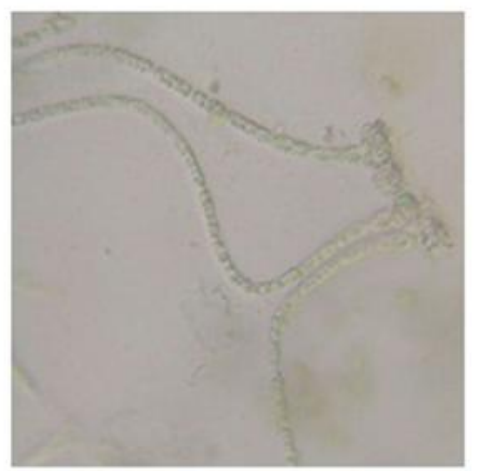

o) Desmidium

Fig. 4 | Phytoplanktons of Serlui 'B' dam. 


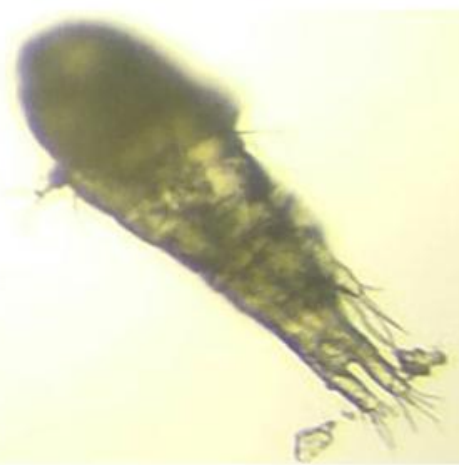

a) Calanoid

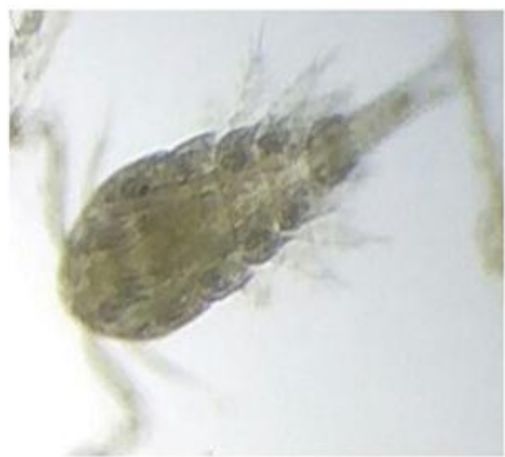

d) Cyclops

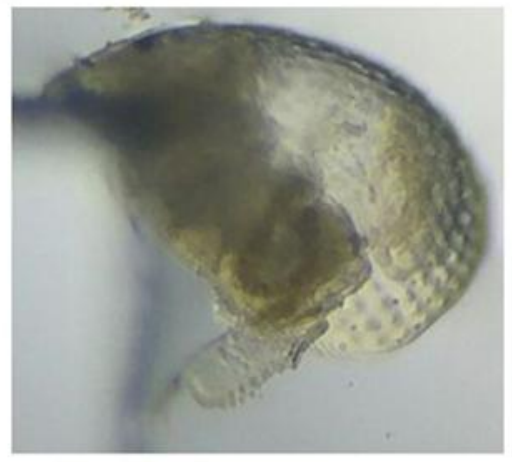

g) Chydorus

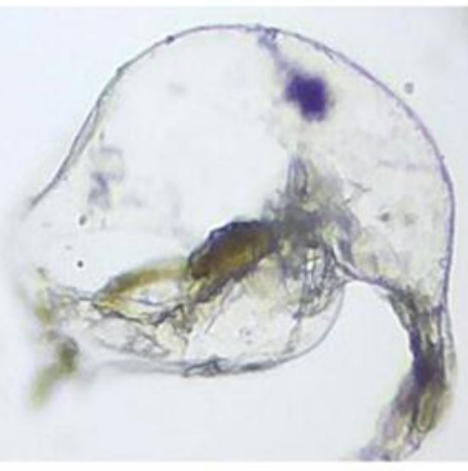

b) Bosmina

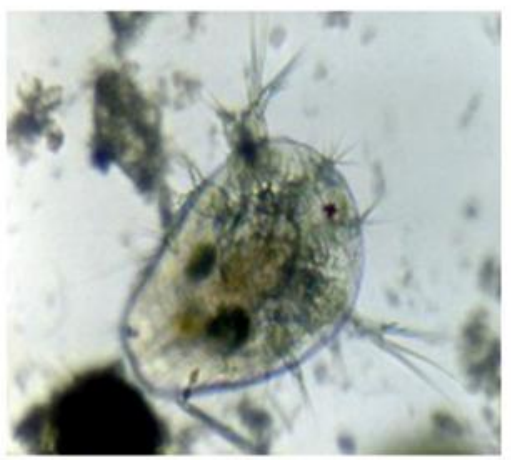

e) Nauplius

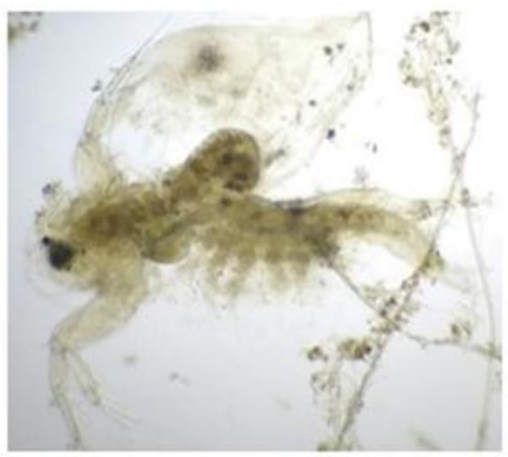

h) Leptodora

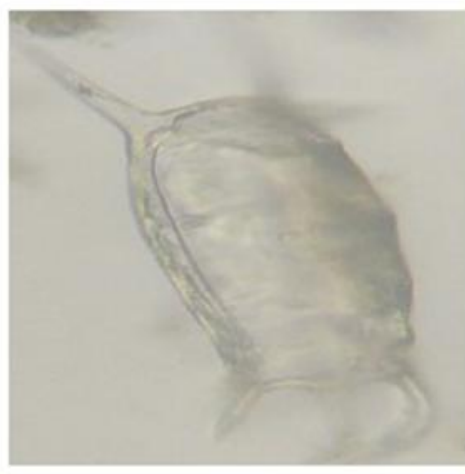

c) Keratella

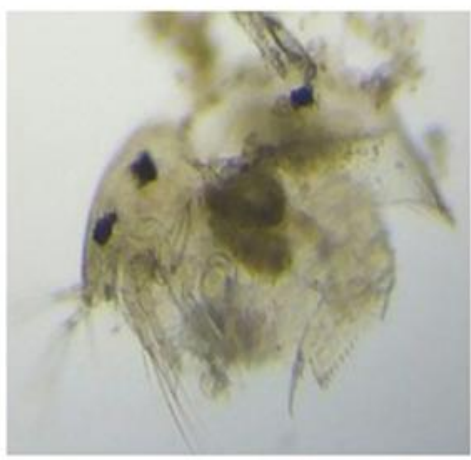

f) Acroperus

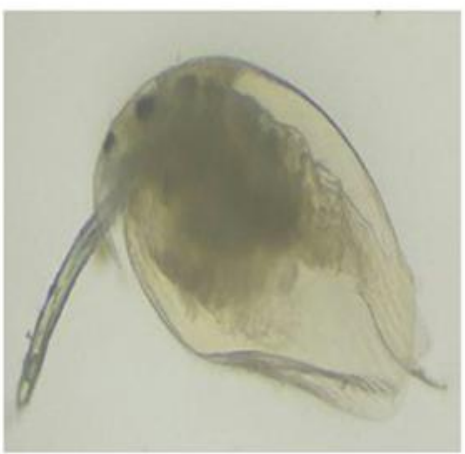

i) Alona

Fig. 7 | Zooplanktons of Serlui 'B' dam. 


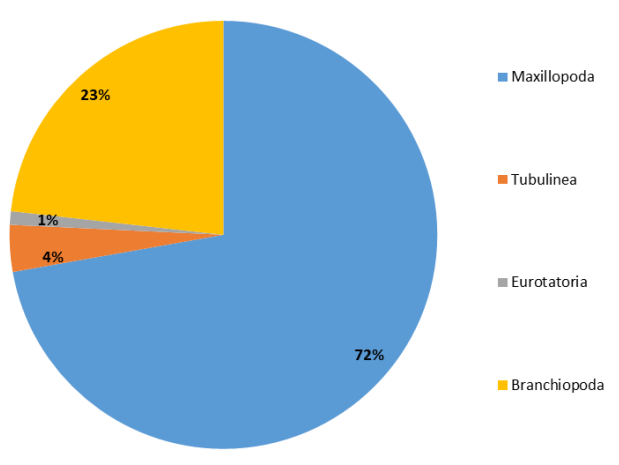

Fig. 5 | Overall group distribution of zooplankton in Serlui 'B' dam.

ent water bodies determines the dominant phytoplankton, their seasonality and variability. ${ }^{17}$

A total of 12 genera of zooplanktons belonging to 7 orders and 4 groups were encountered during the sampling period (Table 2). The zooplankton groups consisted of Maxillopoda, Tubulinea, Eurotatoria and Branchiopoda (Fig. 5). Of these, the class Maxillopoda (Copepoda) was the predominant component of zooplankton in Serlui 'B' dam during all season in terms of numerical abundance. They account for $72 \%$ of the total group encountered during the study period and consisted of 4 genera viz. Nauplius, Cyclops, Calanoid and Diaptomus. Among the most dominant Copepoda was Calanoid belonging to order Calanoida constituting $50 \%$ of the group and $36 \%$ of the total zooplankton population. Branchipoda (Cladocera) formed the second most dominant group comprising about $23 \%$ of the total zooplankton count. The cladocerans were mostly represented by Alona which constitutes $61 \%$ of the group and $14 \%$ of the total zooplankton. Overall, winter season harbors maximum number of zooplankton where $55 \%$ of the total zooplankton was encountered (Fig. 6). Zooplankton showed a minimum peak during spring comprising only $20 \%$ of the total zooplankton population. However the same groups and genera were dominant, although they were present in smaller numbers. The least dominant group among the zooplankton was Eurotatoria consti-

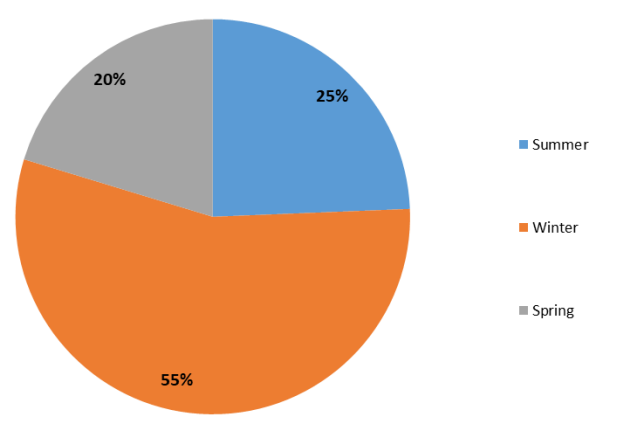

Fig. 6 | Seasonal distribution of zooplankton in Serlui 'B' dam.

tuting only $1 \%$ of the total zooplankton population. In winter, the copepods dominated the zooplankton community accounting for $80 \%$ of the total zooplankton population. Acroperus and Sida were reported only during the summer season while Chydorus was reported during winter season only (Fig. 7). Branchiopoda, the secondmost dominant group comprising of 6 genera were the most diversified among the zooplankton encountered during the sampling period.

The high population of copepods (Maxillopoda) from the study site may be attributed to the moderately rich nutrient nature of the Serlui 'B' dam which supplies them with bacteria serving as a food source for small crustaceans or early stages of small crustaceans. ${ }^{18}$ Unlike the phytoplankton where summer season harbored maximum number of individuals, the zooplankton are found most abundantly during the winter season (Fig. 6). This is in accordance with earlier work done by Pachuau et al. ${ }^{19}$ on Khawiva reservoir where maximum zooplanktons were reported during December and minimum during the month of May.Lalhmingliani et al. ${ }^{20}$ also reported maximum zooplanktons during winter from Tamdil, Mizoram.

\section{Conclusion}

The findings of the present study showed that Serlui ' $B$ ' dam is rich in a wide variety of planktons indicating that it is a good, nutrient 
rich ecosystem, able to support culture fishery and sustain tremendous diversity of flora and fauna. However the short sampling duration is not sufficient to reflect the real status of the dam with respect to plankton diversity. The physiochemical property of the water determines the density and diversity of the planktonic community. Thus overall planktonic composition and abundance is expected to show changes with respect to seasons. This study provides preliminary report of planktons of Serlui 'B' dam.

\section{Acknowledgement}

The authors are grateful to Prof. G. Gurusubramanian, Head, Department of Zoology for providing laboratory facilities to perform the work. The authors also acknowledged Mr. Malsawmkima for his assistance in field work.

\section{References}

I. Singh, S.P., Pathak, D. \& Singh, R. (2002). Hydrobiological studies of two ponds of Satna (M.P) India. Ecology Environment and Conservation 8(3), 289-292.

2. Kedar, G.T \& Patil, G.P (20II). Study on seasonal fluctuation in physico-chemical parameters of Rishi Lake, Karanja (Lad), Dist. Washim, Maharashtra. Proceedings of UGC Sponsored National Level Conference on Environmental Biology and Biodiversity, NCEBB, pp. I2O-I22.

3. Biligrami, K.S. (1988). Biological Monitoring of Rivers Problems and Prospects. Proceedings of the Indian National Science Academy B54 (2\&3), I71-174.

4. APHA (1985) American Water Works Association (AWWA) and Water Pollution Control Federation (WPCF). In: Standard Methods for the examination of $W$ ater and $W$ astewater, I6th Edition (A.E. Greenberg, R.R. Trussell \& L.S. Clesceri eds), Washington DC.

5. Fristch, F.E. (1935). The Structure and Reproduction of Algae Vol I. Cambridge. pp. I-79I.

6. Davis, C.C. (1955). The Marine and Freshwater Plankton. Constable and Company Ltd., London, pp. 539.

7. Edmondson, W.T. (1959). Freshwater Biology (2nd Edition). John Wiley and sons, Inc., N.Y. pp. I-4I2.

8. Prescott, G.W. (1982). Algae of the Western Great Lakes Area. Otto Koeltz Science Publishers West Germany.
9. Needham, J.G \& Needham, P.R. (1972). A Guide to the Study of Freshwater Biology (sth Edition). Holden-Day, Inc., Sansone Street, San Francisco, C.A. pp. IO5.

ı. Tundisi, J.G., Tundisi, M.T. \& Calijuri, M.C. (1993). Limnology and Management of Reservoir in Brazil. (M. Straskraba, J.G. Tundisi \& A. Duncan eds); Comparative reservoir Limnology and water quality Management. pp. 25-55. Kluer Academic Publishers. The Netherlands.

II. Sladecek, V. (1983). Rotifers as indicators of water quality. Hydrobiologia 100, 169-20I.

I2. Murugan, N., Murugavel, P. \& Kodarkar, M.S. (1998). Cladocera: The biology, Classification, Identification and Ecology. Indian Association of Aquatic Biologists (IAAB), Hyderabad.

13. Marcus, N. (2004). An overview of the impacts of eutrophication and chemical pollutants on copepods of the coastal zone, Zoological Studies 43 (2), 2II-2I7.

I4. Naik, U.G., Bhosale, S.H., Rathod, J.L. \& Bhat, U.G. (2005). Diversity of phytoplanktonic groups in the river Kali, west coast of India. Proceedings of the State Level UGC Sponsored Seminar on Biodiversity and its Conservation, Haveri. pp. 192-196.

15. Zargar, S. \& Ghosh, T.K. (2006). Influence of cooling water discharges from Kaiga nuclear power plant on selected indices applied to plankton population of Kadra reservoir. Journal of Environmental Biology 27, 9I -198 .

16. Nandan, S.N. \& Aher, N.H. (2006). Algal community used for assessment of water quality of Harabareer dam and Mosam river of Maharashtra. Journal of Environmental Biology 26, 223-227.

17. Gopal, B. \& Zutshi, D.P. (1998). Remarks on the present status of limnology in India based on the Indian publication in Hydrobiologia and suggestion for future approach. Hydrobiologia 72, 2II-222.

18. Trivedy, R.K., Garud, J.M. \& Goel, P.K. (1985). Studies on Chemistry and Phytoplankton of freshwater bodies in Kolhapur with special reference to human activity. Journal of Pollution Research 4(I), 25-44.

19. Pachuau, L. \& Sharma, B. K. (2013). Zooplankton diversity of a sub-tropical reservoir of Mizoram, Northeast India. Opuscula Zoologica Budapest 44(I), 47-6o.

2o. Lalhmingliani, E. \& Ralte, J.L.B. (2016). Preliminary assessment of plankton diversity in Tam Dil, Mizoram, Northeast India. In: Science and Technology for Shaping the Future of Mizoram. Proceedings of the Mizoram Science Congress. Allied Publishers Pvt. Ltd. India, pp. $39-42$. 